Vol. 2 | No. 3 | 2021 | Hal. 233-237

\title{
MENGATASI KURANGNYA KESADARAN MASYARAKAT DALAM PENERAPAN PROTOKOL KESEHATAN
}

\author{
Nofi Sri Utami*, Muhammad Muammar Al Qodafi, Muh Arif Rahman, Thariq Iqbal, \\ Rayhan Muzakki, Fatkur Rozaq \\ Fakultas Hukum, Universitas Islam Malang \\ *korespondensi email: dr.noficy@unisma.ac.id
}

\begin{abstract}
ABSTRAK
Pada kegiatan Kandidat Sarjana Mengabdi kepada masyarakat permasalahan yang kita angkat yaitu kurangnya kesadaran masyarakat untuk menaati protokol kesehatan untuk mengurangi resiko penyebaran dan juga tertularnya virus COVID 19. Masyarakat seperti enggan memakai masker, kurang sadar dengan mencuci tangan setalah melakukan aktivitas diluar rumah, oleh karena itu kami memberikan edukasi agar masyrakat bisa meningkatkan kesadaran dan pentingnya menaati protokol kesehatan yang sesuai dengan anjuran pemerintah. Metode yang kami gunakan yaitu sosialisai cara terhindar dari virus, pembagian masker, pembuatan tempat cuci tangan di tempat yang biasa dikunjungi banyak orang, dan juga pembuatan poster tentang pentingnya menaati protokol kesehatan. Masyarakat merasa senang dan juga terbantu dengan adanya kegiatan ini karena dapat memberikan informasi penting mengenai kesehatan diri, mencegah tertularnya virus COVID 19, serta mematuhi protokol kesehatan.
\end{abstract}

Kata Kunci: covid-19; protokol; masyarakat

\section{PENDAHULUAN}

Wabah COVID 19 yang telah menular di berbagi negara termasuk Indonesia telah mempengaruhi seluruh masyarakat. Penyebaran penyakit ini telah memberikan dampak besar secara sosial maupun ekonomi yang disebabkan oleh jumlah kasus yang semakin hari semakin bertambah. Salah satu anjuran WHO kepada masyarakat yaitu tetap menggunakan masker dalam upaya penekanan penyebaran virus ini (Hapsari \& Munawi,2021; Masruroh \& Hayati, 2021).

Wabah ini tidak hanya merupakan permasalahan global. Virus tersebut juga menyebar dengan sangat cepat dan bisa mematikan, cara menularnya dengan kontak fisik yang ditularkan dari mulut, mata, dan juga hidung (Siahaineinia \& Bakara, 2020). Dampak dari wabah terhadap pelayanan publik dan upaya penanggulanganya masih menjadi permasalahan. Untuk mencegah wabah agar tidak semakin menyebar dibutuhkan kerja sama dari semua lapisan masyarakat seperti pemerintah, masyrakat, dan juga tokoh agama agar saling bahu membahu dan saling membantu satu sama lain dalam melawan COVID 19.

Untuk itu kami berinisiatif untuk mengajak masyarakat untuk selalu menaati protokol kesehatan dan memberikan edukasi kepada masyarakat agar lebih memahami pentingnya menaati protokol kesehatan, mengingat kondisi masyarakat yang kurang memahami pengetahuan tentang COVID 19 diperlukan adanya sosialisasi. Kami melakukan kegiatan ini dengan alasan untuk mendukung usaha pencegahan penularan COVID 19 karena 
pada masa pandemi ini masih banyak masyarakat yang kurang sadar pentingnya memakai masker saat keluar dari rumah, jarang mencuci tangan, dan tidak menjaga jarak satu sama lain (Rahmawati et al., 2021).

Beberapa cara yang dilakukan untuk mengangkat kesadaran masyarakat bahwa penting dalam menaati protokol kesehatan untuk mencegah resiko tinggi tertularnya virus COVID 19 seperti sosialisasi kepada masyarakat, pembagian masker, permbuatan tempat cuci tangan, hingga pembuatan poster. Kegiatan ini sangatlah penting karena kita semua tahu masih banyak yang belum mematuhi protokol kesehatan di berbagai kalangan masyrakat.

\section{METODE}

Kegiatan yang kami lakukan ini merupakan salah satu dari program kerja untuk memenuhi tugas KSM (Kandidat Sarjana Mengabdi) yang diselenggarakan oleh LPPM Universitas Islam Malang. Sasaran dalam kegiatan kali ini adalam masyrakat Dusun Lasah, Desa Tawangargo, Kec. Karangploso, Kab. Malang. Pemilihan sasaran tersebut berdasarkan dari persetujuan perangkat desa setempat. Metode kegiatan ini berupa partisipasi dari masyarakat dalam kegiatan pembagian masker, sosialisasi pencegahan COVID 19, pembuatan tempat cuci tangan, dan juga pemasangan poster menganai protokol kesehatan. Rangkaian kegiatan ini dimulai pada tanggal 1 Agustus hingga 14 September 2021 di Dusun Lasah, Kelurahan Tawangargo, Kec. Karangploso, Kab. Malang.

Metode pertama yaitu pemesanan masker, pembelian masker yang disesuaikan dengan jumlah penduduk yang berada di Dusun lasah dimana setiap orang nantinya mendapatkan 3 buah masker. Selanjutnya kami melaksanakan pembagian kesetiap lingkungan masyarakat yang ada di Dusun Lasah.

Metode kedua, bekerja sama dengan karang taruna desa setempat dan bergabung dengan grup Whatsapp karang taruna, untuk mengundang pemuda pemuda karang taruna dalam kegiatan sosialisasi, dimana nantinya para pemuda karang taruna tersebut yang akan membagikan informasi kepada setiap grup Whatsapp Rukun Tetangga setempat. Metode ini dilakukan agar tidak terjadi banyaknya kerumunun jika kita langsung yang mengundang warga untuk kegiatan sosialisasi.

Metode ketiga, kami mencari informasi mengenai tempat tempat dimana warga sering berkumpul seperti masjid, musholah, sekolah, kantor desa, hingga pos kamling. Tujuan dari pencarian informasi tersebut karena kami ingin membuat tempat cuci tangan di tempat yang sering dikunjungi warga. Informasi yang didapatkan masih banyak tempat tempat yang belum memiliki tempat cuci tangan. Langkah selanjutnya yang kami ambil yaitu pembelian peralatan tempat cuci tangan sejumlah tempat yang kita sudah ketahui dari informasi, lalu kemudian langsung memasang ditempat tersebut.

Terakhir, untuk metode keempat kami mencari referensi mengenai protokol kesehatan untuk memudahkan dalam pembuatan desain poster yang akan dipasangkan ditempat tempat yang sering dikunjungi warga. Setelah itu kami segera membuat desain poster dan dilanjutkan dengan pencetakan poster mengenai protokol kesehatan. Poster poster ini nantinya akan dipasang di pos kamling, mading masjid atau mushollah, sekolah, dan juga balai dusun tidak lupa meminta izin terlebih dahulu ke pihak terkait untuk dipasang poster.

\section{HASIL DAN PEMBAHASAN}

\section{Hasil Dari Penyelesaian Masalah 1}

Metode pertama yaitu pemesanan masker, pembelian masker yang disesuaikan dengan jumlah penduduk yang berada di Dusun lasah dimana setiap orang nantinya 
mendapatkan 3 buah masker. Selanjutnya kami melaksanakan pembagian kesetiap lingkungan masyarakat yang ada di Dusun Lasah. Masih banyak warga yang kurang sadar pentingnya penggunaan masker sehari hari. Proses pembagian masker ini berlangsung seperti pada gambar 1 berikut.

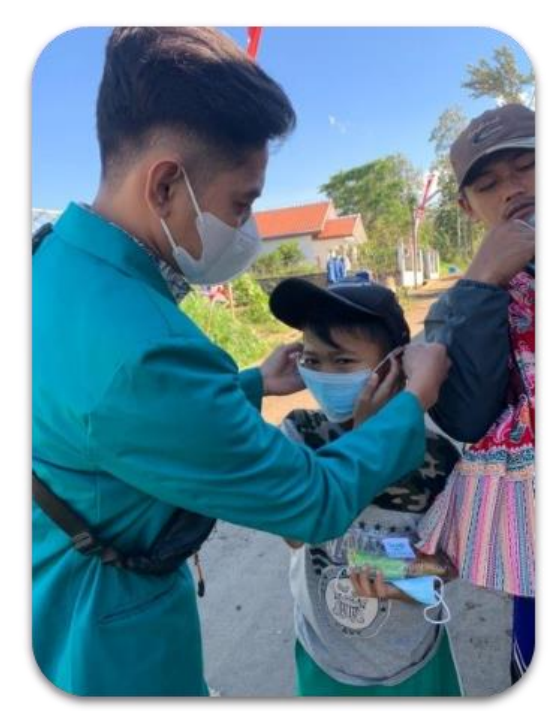

Gambar 1. Pembagian masker kepada masyarakat

Kegiatan ini dapat meningkatkan kesadaran masyarakat supaya mematuhi protokol kesehatan selama pandemi ini yaitu salah satunya dengan menggunakan ketika beraktivitas diluar rumah.

\section{Hasil Dari Penyelesaian Masalah 2}

Metode kedua, bekerja sama dengan karang taruna desa setempat dan bergabung dengan grup Whatsapp karang taruna, untuk mengundang pemuda pemuda karang taruna dalam kegiatan sosialisasi, dimana nantinya para pemuda karang taruna tersebut yang akan membagikan informasi kepada setiap grup Whatsapp Rukun Tetangga masing masing. Metode ini dilakukan agar tidak terjadi banyaknya kerumunun jika kita langsung yang mengundang warga untuk kegiatan sosialisasi. Kegiatan ini bertujuan untuk meningkatkan kembali kesadaran warga dalam patuh terhadapat protokol kesehatan untuk mengurangi dan juga menghindari penularan virus. Kegiatan sosialisasi ini bisa dilihat pada gambar 2.

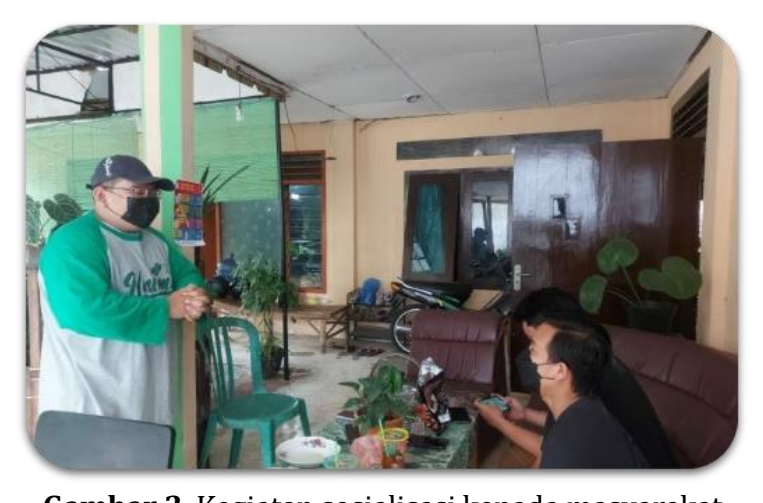

Gambar 2. Kegiatan sosialisasi kepada masyarakat

\section{Hasil Dari Penyelesaian Masalah 3}

Metode ketiga, kami mencari informasi mengenai tempat tempat dimana warga sering berkumpul seperti masjid, musholah, sekolah, kantor desa, hingga pos kamling. 
Tujuan dari pencarian informasi tersebut karena kami ingin membuat tempat cuci tangan di tempat yang sering dikunjungi warga. Informasi yang didapatkan masih banyak tempat tempat yang belum memiliki tempat cuci tangan. Langkah selanjutnya yang kami ambil yaitu pembelian peralatan tempat cuci tangan sejumlah tempat yang kita sudah ketahui dari informasi, lalu kemudian langsung memasang ditempat tersebut. Langkah ini memberikan dampak positif bagi warga untuk mulai membiasakan cuci tangan.

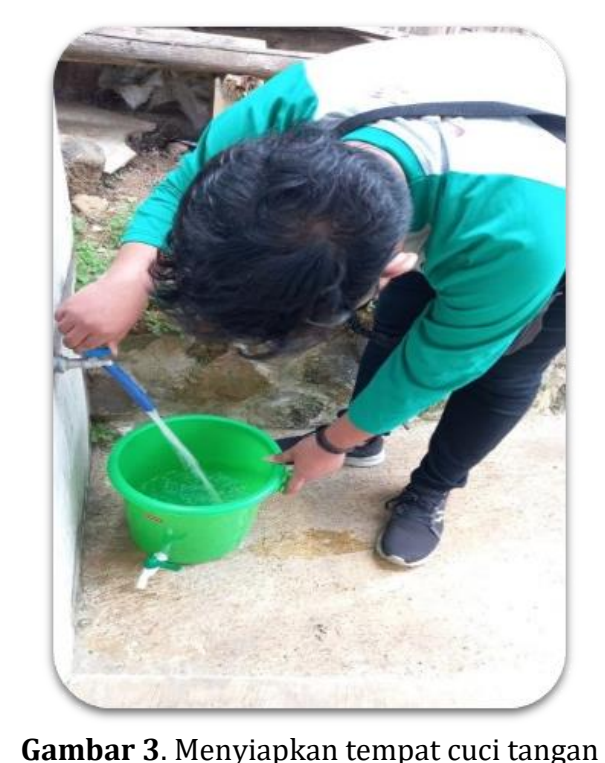

\section{Hasil Dari Penyelesaian Masalah 4}

Terakhir, untuk metode keempat kami mencari referensi mengenai protokol kesehatan untuk memudahkan dalam pembuatan desain poster yang akan dipasangkan ditempat tempat yang sering dikunjungi warga. Setelah itu kami segera membuat desain poster dan dilanjutkan dengan pencetakan poster mengenai protokol kesehatan. Poster poster ini nantinya akan dipasang di pos kamling, mading masjid atau mushollah, sekolah, dan juga balai dusun tidak lupa meminta izin terlebih dahulu ke pihak terkait untuk dipasang poster. Dalam kegiatan ini juga sangat bermanfaat bagi warga karena dapat mengingatkan kapan pun mengenai pentingnya taat protokol kesehatan.

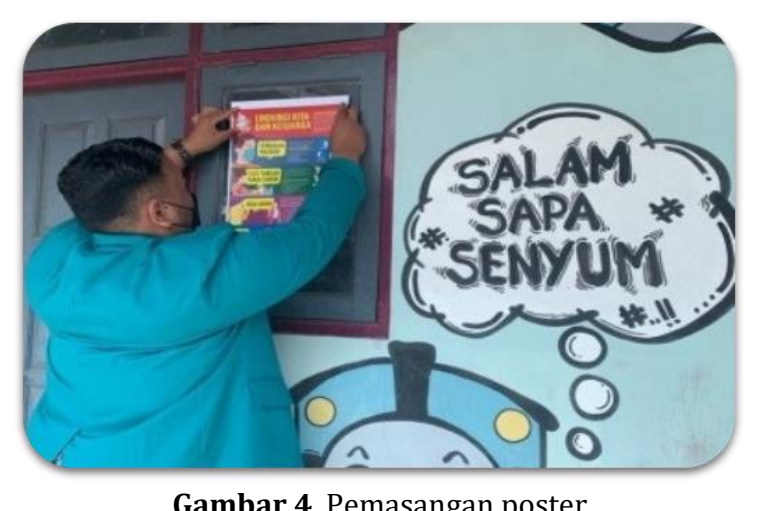

Dalam langkah ini kami mendesain poster yang akan dipasang. Adapun desain poster yang akan dipasang seperti pada gambar berikut: 


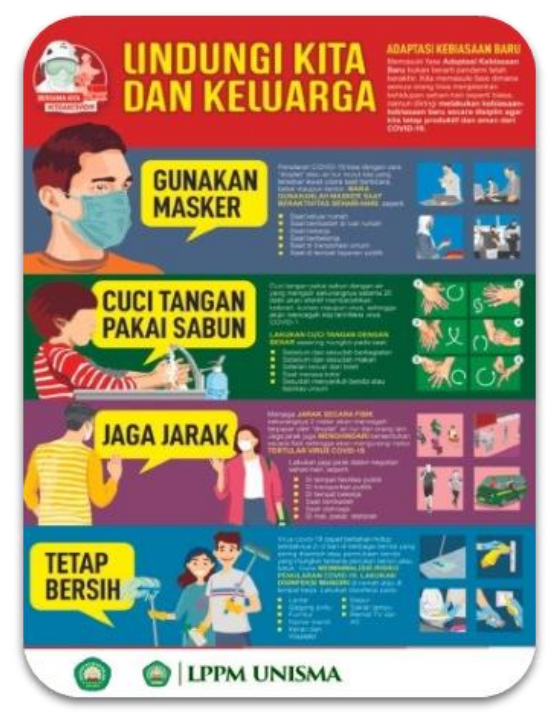

Gambar 5. Model poster

\section{KESIMPULAN}

Masyrakat harus meningkatkan kesadaran dalam taat protokol kesehatan, seperti menggunakan masker, rajin mencuci tangan, dan juga menjaga jarak. Karena kita tidak tahu pandemi ini berakhir. Adapun hasil dari program kerja kali ini yaitu meningkatkan kesadaran warga dalam mencegah penyebaran virus dilingkungan masyrakat Dusun Lasah dengan pembagian masker, pembuatan tempat cuci tangan, penempelan poster ditempat tempat yang sering dikunjungi warga, dan juga sosialisasi terkait protokol kesehatan. Dalam pelaksanaan kegiatan Kandidat Sarjana Mengabdi (KSM) yang dilaksanakan di Dusun Lasah, Desa Tawangargo, Kec. Karangploso, Kab.Malang.

\section{DAFTAR RUJUKAN}

Astiwi Kurniati, B. A. (2021). MENINGKATKAN KESADARAN MASYARAKAT MEMATUHI PROTOKOL KESEHATAN SEBAGAI UPAYAPENCEGAHAN COVID-19. MENINGKATKAN KESADARAN MASYARAKAT MEMATUHI PROTOKOL KESEHATAN SEBAGAI UPAYAPENCEGAHAN COVID-19.

Ayunda Ramadhani, L. S. (2020). MENJAGA KESEHATAN DI TENGAH PANDEMI COVID-19. MENJAGA KESEHATAN DI TENGAH PANDEMI COVID-19 DENGAN MENINGKATKAN KESADARAN MASYARAKAT.

Hapsari, K. R. (2021). Pemilihan Masker Kain dalam MencegahPenularan Virus Covid-19. Nusantara of Engineering,

Masruroh, \& Hayati, N. (2021). Media poster sebagai sarana edukasi masyarakat dalam upaya pencegahan covid-19. Jurnal Inovasi Hasil Pengabdian Masyarakat (JIPEMAS), 4(36), 169-176. https://doi.org/10.33474/jipemas.v4i2.9207

Rahmawati, R. R. (2021). Edukasi Protokol Kesehatan dalam Menjalankan New Normal di Masa Pandemik Melalui Media Poster. In Prosiding SeminarNasional Pengabdian Masyarakat LPPM UMJ.

Siahaineinia, H. E. (2020). Persepsi Masyarakat Tentang Penggunaan Masker Dan Cuci Tangan Selama Pandemi Covid-19 di Pasar Sukaramai Medan. Wahana Inovasi:Jurnal Penelitian dan Pengabdian Masyarakat UISU. 